\title{
ChemComm
}

\section{Nickel-catalyzed asymmetric transfer hydrogenation of conjugated olefins $\dagger$}

Cite this: Chem. Commun., 2015, 51, 12115

Received 24th February 2015 Accepted 11th June 2015

DOI: $10.1039 / \mathrm{c5cc01632k}$

www.rsc.org/chemcomm

Asymmetric transfer hydrogenation of electron-deficient olefins is realized with nickel catalysts supported by strongly $\sigma$-donating bisphosphines. Deuterium labeling experiments point to a reaction sequence of formate decarboxylation, asymmetric hydride insertion and non-stereoselective protonation of resulting nickel enolates.

Asymmetric hydrogenation is the state-of-the-art example in homogeneous metal catalysis and it is practiced on large scales in the manufacturing of chiral pharmaceuticals and agrochemicals. ${ }^{1}$ Today, chiral catalysts of noble metals such as $\mathrm{Rh}^{2}{ }^{2} \mathrm{Ru}^{3}$ and $\mathrm{Ir}^{4}$ dominate the field of asymmetric hydrogenation. Expensive noble metals themselves contributed to a fraction of the total cost of hydrogenation processes, in addition to costly chiral bisphosphines. Furthermore, the mining and purification of these rare metals from ores is energy demanding and costly. These metals are produced in only dozens of tons a year worldwide and are very expensive, often thousand-fold more so than abundant metals such as copper and nickel. They are highly toxic to human and ecosystems. The heavy metal residues in pharmaceutical active ingredients must be reduced to ppm levels according to FDA regulations. Waste treatment after catalytic hydrogenation also incurs additional costs. In comparison, base metals like iron, nickel and copper are much cheaper, less toxic or even nontoxic, and are being produced in millions of tons a year. ${ }^{5}$

Previously, Pfaltz et al. invented cobalt-catalyzed asymmetric reduction using borohydrides. ${ }^{6}$ Recently, Chirik's group reported cobalt-catalyzed hydrogenation of styrenes and enamides, but the cobalt catalysts were sensitive to air and moisture and the types of olefins that gave high ee were quite limited. ${ }^{7}$ In recent years, achiral nickel complexes were found to have non-stereoselective hydrogenation activity towards unsaturated bonds. ${ }^{8}$ Hamada et al. reported nickel-catalyzed hydrogenation of ketone groups of $\alpha$-amino- $\beta$-ketoesters under dynamic kinetic resolution conditions

Division of Chemistry and Biological Chemistry, School of Physical and Mathematical Sciences, Nanyang Technological University, 21 Nanyang Link, Singapore 637371. E-mail: jrzhou@ntu.edu.sg; Fax: +65 67911961

$\dagger$ Electronic supplementary information (ESI) available: Experimental procedures and characterization of isolated products. See DOI: $10.1039 / \mathrm{c} 5 \mathrm{cc} 01632 \mathrm{k}$ (around $80 \%$ ee). ${ }^{9}$ Recently our group disclosed highly stereoselective nickel catalysts for transfer hydrogenation of enamides and hydrazones having directing groups. ${ }^{10}$ Formic acid was used as a safe and easy-to-handle hydrogen source. It has a high volume/ density of $\mathrm{H}_{2}$ and is a promising hydrogen storage material. ${ }^{11}$ In recent years, highly efficient metal catalysts were developed for decomposition of formic acid to release $\mathrm{H}_{2} \cdot{ }^{12}$ In comparison, both high-pressure hydrogen gas and liquid are safety hazard during storage, transport and use.

Herein, we report a nickel/DuPhos catalyst for asymmetric transfer hydrogenation of conjugated olefins using formic acid. ${ }^{13}$ DuPhos, which was invented by Mark Burk, was uniquely active and gave $91 \%$ ee value in the model reaction (Fig. 1). The performance of other bisphosphines was unsatisfactory. ( $S$ )-Binapine was completely inactive. Other bisphosphine showed little activity, including Ph-BPE, Me-DPF, DuanPhos, QuinoxP* ${ }^{*}$ and Josiphos ligands. ${ }^{14}$ TangPhos was moderately active. ${ }^{15}$ Less donating bis(biarylphosphine)s including BINAP, Segphos and DIPAMP were completely inactive. PHOX (Pfaltz ligand) and Feringa's phosphoramidites

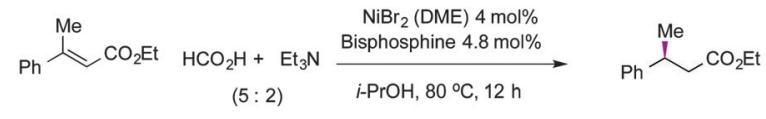

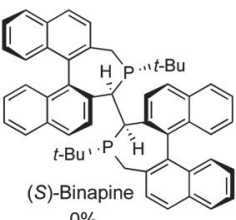

$0 \%$
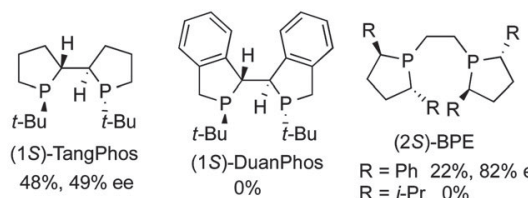

(2S)-BPE $\mathrm{R}=\mathrm{Ph} 22 \%, 82 \%$ ee $\mathrm{R}=i-\operatorname{Pr} \quad 0 \%$

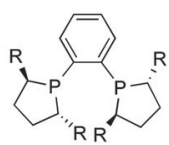

(2R)-DuPhos

$\mathrm{R}=\mathrm{Me} 92 \%, 91 \%$ ee

$\mathrm{R}=\mathrm{Et} \quad 0 \%$
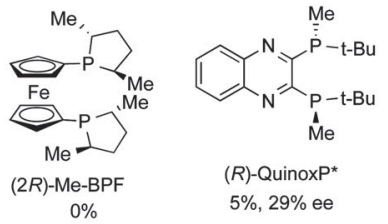

(R)-Quinox $\mathrm{P}^{*}$ $5 \%, 29 \%$ ee

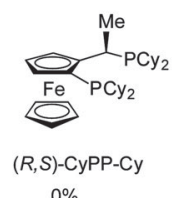

$0 \%$
Fig. 1 Performance of chiral bisphosphines in the model reaction of $\beta$-methylcinnamate. 
Table 1 Solvent effect for the model hydrogenation of ethyl $(E)$ - $\beta$-methylcinnamate (GC yields and conversion on $0.1 \mathrm{mmol}$ scale)

\begin{tabular}{|c|c|c|c|c|}
\hline & $\mathrm{CC}$ & $\begin{array}{l}\mathrm{NiBr}_{2}(\mathrm{DME}) 4 \mathrm{~mol} \% \\
(R)-\mathrm{Me}-\mathrm{Duphos} 4.8 \mathrm{~mol} \% \\
\underset{\mathrm{HCO}_{2} \mathrm{H} / \mathrm{Et}_{3} \mathrm{~N}(5: 2)}{80^{\circ} \mathrm{C}, 12 \mathrm{~h}} \\
\text { model reaction } \\
\end{array}$ & $\mathrm{Ph}^{\mathrm{Me}}$ & \\
\hline Entry & Conditions & Conv. (\%) & Yield (\%) & ee $(\%)$ \\
\hline 1 & $\mathrm{MeOH}$ & 45 & 45 & 90 \\
\hline 2 & EtOH & 98 & 95 & 90 \\
\hline 3 & $n$-BuOH & 95 & 92 & 91 \\
\hline 4 & i-PrOH & 99 & 92 & 91 \\
\hline 5 & DMF & 88 & 87 & 91 \\
\hline 6 & Diglyme & 97 & 96 & 93 \\
\hline 7 & THF & 53 & 39 & 92 \\
\hline 8 & Toluene & 72 & 55 & 93 \\
\hline 9 & $\mathrm{PhCF}_{3}$ & 83 & 81 & 94 \\
\hline
\end{tabular}

did not form active catalysts. Iron, cobalt and copper salts were tested with Me-DuPhos and did not form active catalysts.

Isopropanol was used as a solvent in isolation experiments. The nickel catalyst worked well in several other alcohols and diglyme (Table 1). No hydrogenation activity was detected with 10 atm of $\mathrm{H}_{2}$.

$(E)$-Cinnamates having small $\beta$ groups $c$ is to the ester groups reacted to afford good ee (Fig. 2). The (Z)-geometric isomer afforded only $<20 \%$ ee, however. Electron-donating or withdrawing groups on aryl groups were well tolerated, as well as thiophene and pyridine rings. Cyclic olefins were also hydrogenated efficiently to give tetraline derivatives. Furthermore, the ester groups can be replaced by amides and nitriles. $\alpha$-Phenylmaleate gave $94 \%$ ee in the presence of a TangPhos catalyst, while the DuPhos catalyst gave only $65 \%$ ee (Fig. $2 \mathrm{~b}$ ). The reaction can be scaled up to gram scale with $2 \mathrm{~mol} \%$ of nickel (Fig. 2c). In the case of $p$-chloro- $\beta$-methylcinnamate, its aryl-Cl bond was reduced to $\mathrm{C}-\mathrm{H}$ in the isolated product. It was probably caused by oxidative addition of the $\mathrm{C}-\mathrm{Cl}$ bond to a nickel( $(0)$ species. A $\beta, \beta$-dialkylacrylate was also attempted which afforded a moderate $54 \%$ ee. Simple styrene derivatives did not react.

When we attempted the model reaction using $\left[\mathrm{D}_{2}\right]$ formic acid (Fig. 3a), the $\beta$ position was fully deuterated as expected. Both $\alpha$ and $\alpha^{\prime}$ positions were partially deuterated, too. The deuterium content at $\alpha$ and $\alpha^{\prime}$ positions added up to around $100 \%$. Most likely, the main pathway consists of formate decarboxylation on nickel, hydride insertion of the olefin and subsequent non-stereoselective protonation of resulting enolates (Fig. 3a). ${ }^{16}$ This pathway is distinct from syn-addition of $\mathrm{H}_{2}$ in classical dihydride and monohydride pathways using noble metal catalysts. ${ }^{17}$

Surprisingly, when we used $\left[\mathrm{D}_{1}\right]$ formic acid (Fig. $3 \mathrm{~b}$ ), besides deuteration at $\alpha$ position, a significant amount of deuterium ended up in $\beta$ position (about $30 \% \mathrm{D}$ ). In control experiments, no extra deuteration occurred when the methylcinnamate and its hydrogenation product were treated with $\left[\mathrm{D}_{1}\right]$ formic acid. Direct hydride transfer from a formate to a metal-bound methylcinnamate via a six-membered transition state is inconsistent with $>100 \%$ deuterium incorporation.

We propose a minor reaction pathway that involves an equilibrium of (DuPhos) $\mathrm{Ni}(\mathrm{H})^{+}$and (DuPhos) $\mathrm{Ni}^{0}$ via reversible

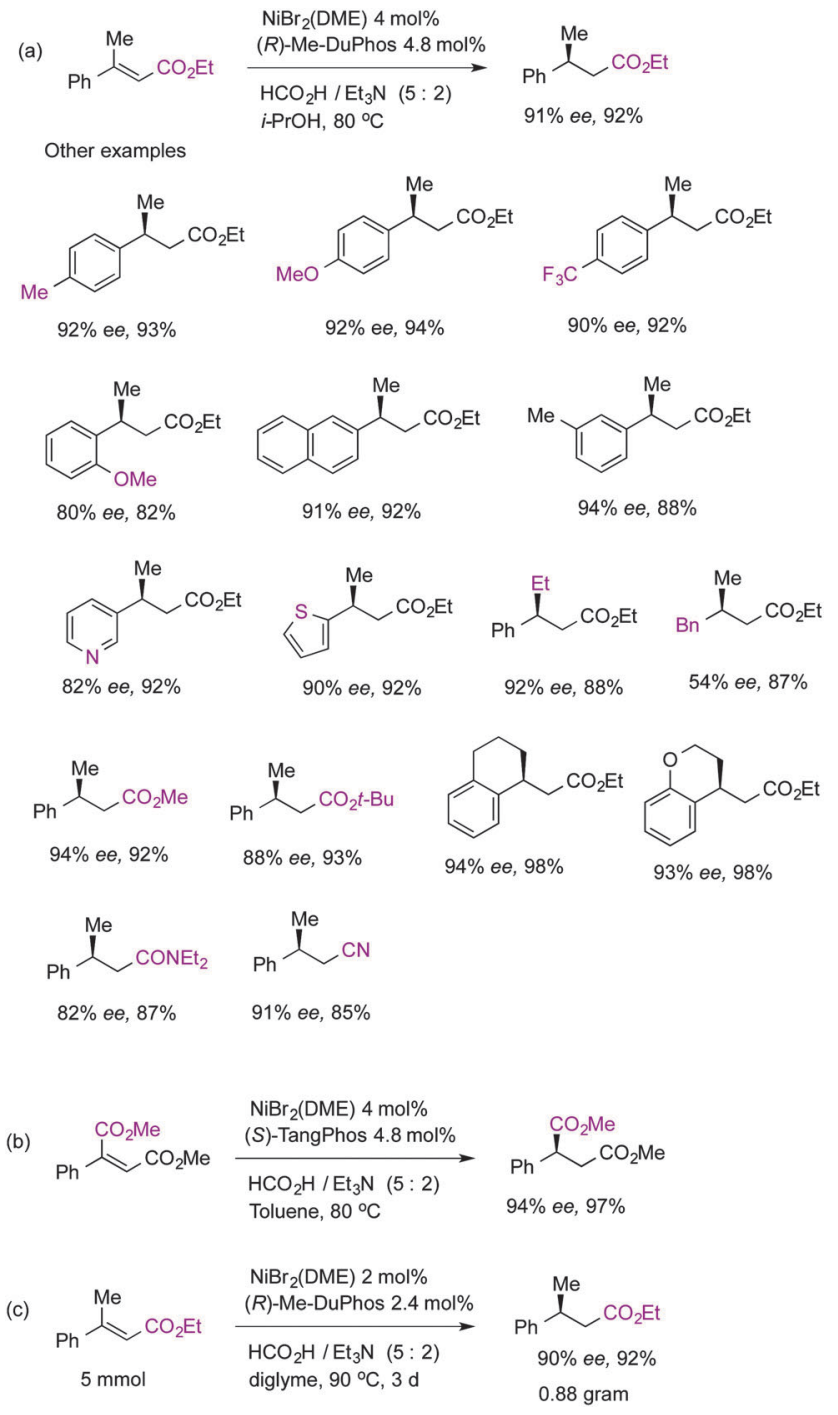

Fig. 2 Examples of transfer hydrogenation (isolated yields from $0.5 \mathrm{mmol}$ of olefins).

deprotonation. This allows a deuteron of $\left[\mathrm{D}_{1}\right]$ formic acid to become a nickel deuteride and eventually add to the $\beta$ position of $\beta$-methylcinnamate (Fig. 3c). ${ }^{18}$ The presence of a nickel(0) species was supported by hydrodechlorination of an aryl C-Cl bond in $p$-chloro- $\beta$-methylcinnamate. As another piece of evidence for nickel( $(0)$, when $\mathrm{Ni}\left(\mathrm{PPh}_{3}\right)_{4}$ was used as a nickel precursor, the model reaction in Table 1 became much slower, but it still afforded $14 \%$ conversion after 24 hours at $100{ }^{\circ} \mathrm{C}$.

In summary, we herein report a nickel-catalyzed transfer hydrogenation of conjugated olefins. The nickel catalyst must be supported by a strongly $\sigma$-donating bisphosphine, probably for efficient decarboxylation of formate. No directing groups are needed on olefins, unlike enamides and ketone hydrazones that we reported previously. ${ }^{10}$ Deuterium labelling experiments point to a major pathway involving formate decarboxylation, hydride insertion into olefins and protonation of resulting nickel enolates.

We thank Singapore GSK-EDB green and sustainable manufacturing award and Nanyang Technological University for financial support. 


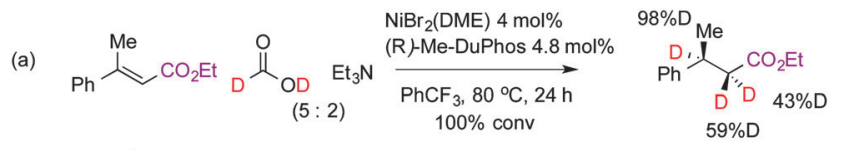$$
\downarrow \mid[(L-L)] N i-X]^{+}+\uparrow \begin{gathered}
\mathrm{DCO}_{2} \mathrm{D} \\
\text { deuteration }
\end{gathered}
$$$$
\left.[(\mathrm{L}-\mathrm{L})] \mathrm{Ni}-\mathrm{OC}(\mathrm{O}) \mathrm{D}]^{+} \underset{\text { decarboxylation }}{\stackrel{-\mathrm{CO}_{2}}{\longrightarrow}}[(\mathrm{L}-\mathrm{L})] \mathrm{Ni}-\mathrm{D}\right]^{+} \underset{\begin{array}{l}
\text { olefin } \\
\text { insertion }
\end{array}}{\longrightarrow} \underset{\begin{array}{c}
(\mathrm{L}-\mathrm{L}) \mathrm{Ni}^{+} \\
\text {or O-enolate }
\end{array}}{\mathrm{Ph}^{\mathrm{Me}}} \mathrm{CO}_{2} \mathrm{Et}
$$

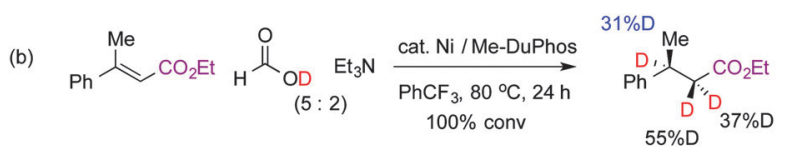

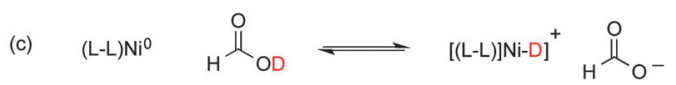

Fig. 3 Deuterium labeling experiments and the reaction mechanism.

\section{Notes and references}

1 (a) W. S. Knowles, Angew. Chem., Int. Ed., 2002, 41, 1998; (b) R. Noyori, Adv. Synth. Catal., 2003, 345, 15; (c) W. Tang and X. Zhang, Chem. Rev., 2003, 103, 3029; (d) I. D. Gridnev and T. Imamoto, Acc. Chem. Res., 2004, 37, 633; (e) X. Cui and K. Burgess, Chem. Rev., 2005, 105, 3272; $(f)$ V. Farina, J. T. Reeves, C. H. Senanayake and J. J. Song, Chem. Rev., 2006, 106, 2734; $(g)$ N. B. Johnson, I. C. Lennon, P. H. Moran and J. A. Ramsden, Acc. Chem. Res., 2007, 40, 1291; (h) A. J. Minnaard, B. L. Feringa, L. Lefort and J. G. De Vries, Acc. Chem. Res., 2007, 40, 1267; (i) S. J. Roseblade and A. Pfaltz, Acc. Chem. Res., 2007, 40, 1402; $(j)$ L. A. Saudan, Acc. Chem. Res., 2007, 40, 1309; (k) H. Shimizu, I. Nagasaki, K. Matsumura, N. Sayo and T. Saito, Acc. Chem. Res., 2007, 40, 1385; (l) W. Zhang, Y. Chi and X. Zhang, Acc. Chem. Res., 2007, 40, 1278; (m) D. J. Ager, A. H. M. de Vries and J. G. de Vries, Chem. Soc. Rev., 2012, 41, 3340; (n) H.-U. Blaser, B. Pugin and F. Spindler, Top. Organomet. Chem., 2012, 1; (o) J. J. Verendel, O. Pàmies, M. Diéguez and P. G. Andersson, Chem. Rev., 2013, 114, 2130; $(p)$ J.-P. Genet, T. Ayad and V. Ratovelomanana-Vidal, Chem. Rev., 2014, 114, 2824.

2 Examples: (a) R. Hoen, J. A. F. Boogers, H. Bernsmann, A. J. Minnaard, A. Meetsma, T. D. Tiemersma-Wegman, A. H. M. de Vries, J. G. de Vries and B. L. Feringa, Angew. Chem., Int. Ed., 2005, 44, 4209; (b) W. Chen, P. J. McCormack, K. Mohammed, W. Mbafor, S. M. Roberts and J. Whittall, Angew. Chem., Int. Ed., 2007, 46, 4141; (c) K. Dong, Y. Li, Z. Wang and K. Ding, Angew. Chem., Int. Ed., 2013, 52, 14191; (d) Y. Li, K. Dong, Z. Wang and K. Ding, Angew. Chem., Int. Ed., 2013, 52, 6748.

3 Examples: (a) T. Ohta, H. Takaya, M. Kitamura, K. Nagai and R. Noyori, J. Org. Chem., 1987, 52, 3174; (b) T. Uemura, X. Zhang, K. Matsumura, N. Sayo, H. Kumobayashi, T. Ohta, K. Nozaki and H. Takaya, J. Org. Chem., 1996, 61, 5510; (c) X. Cheng, Q. Zhang, J.-H. Xie, L.-X. Wang and Q.-L. Zhou, Angew. Chem., Int. Ed., 2005, 44, 1118.

4 Examples: (a) W. Tang, W. Wang and X. Zhang, Angew. Chem., Int. Ed., 2003, 42, 943; (b) S. Li, S.-F. Zhu, C.-M. Zhang, S. Song and Q.-L. Zhou, J. Am. Chem. Soc., 2008, 130, 8584; (c) W.-J. Lu, Y.-W. Chen and X.-L. Hou, Angew. Chem., Int. Ed., 2008, 47, 10133; (d) J. Zhao and K. Burgess, J. Am. Chem. Soc., 2009, 131, 13236; (e) D. Rageot, D. H. Woodmansee, B. Pugin and A. Pfaltz, Angew. Chem., Int. Ed., 2011, 50, 9598; $(f)$ S.-F. Zhu, Y.-B. Yu, S. Li, L.-X. Wang and Q.-L. Zhou, Angew. Chem., Int. Ed., 2012, 51, 8872; (g) M. Bernasconi, M.-A. Müller and A. Pfaltz, Angew. Chem., Int. Ed., 2014, 53, 5385; (h) Y. Liu, I. D. Gridnev and W. Zhang, Angew. Chem., Int. Ed., 2014, 53, 1901.
5 http://www.infomine.com/investment/metal-prices.

6 (a) U. Leutenegger, A. Madin and A. Pfaltz, Angew. Chem., Int. Ed. Engl., 1989, 28, 60; (b) C. Geiger, P. Kreitmeier and O. Reiser, Adv. Synth. Catal., 2005, 347, 249.

7 (a) S. Monfette, Z. R. Turner, S. P. Semproni and P. J. Chirik, J. Am. Chem. Soc., 2012, 134, 4561; (b) M. R. Friedfeld, M. Shevlin, J. M. Hoyt, S. W. Krska, M. T. Tudge and P. J. Chirik, Science, 2013, 342, 1076; (c) R. P. Yu, J. M. Darmon, C. Milsmann, G. W. Margulieux, S. C. E. Stieber, S. DeBeer and P. J. Chirik, J. Am. Chem. Soc., 2013, 135, 13168; hydroboration: (d) L. Zhang, Z. Zuo, X. Wan and Z. Huang, J. Am. Chem. Soc., 2014, 136, 15501.

8 Examples: (a) A. H. Vetter and A. Berkessel, Synthesis, 1995, 419; (b) I. M. Angulo, A. M. Kluwer and E. Bouwman, Chem. Commun., 1998, 2689; (c) I. M. Angulo and E. Bouwman, J. Mol. Catal. A: Chem., 2001, 175, 65; (d) S. Kuhl, R. Schneider and Y. Fort, Organometallics, 2003, 22, 4184; (e) A. L. Iglesias and J. J. Garcia, J. Mol. Catal. A: Chem., 2009, 298, 51; $(f)$ W. H. Harman and J. C. Peters, J. Am. Chem. Soc., 2012, 134, 5080; $(g)$ K. V. Vasudevan, B. L. Scott and S. K. Hanson, Eur. J. Inorg. Chem., 2012, 4898; (h) J. Wu, J. W. Faller, N. Hazari and T. J. Schmeier, Organometallics, 2012, 31, 806; (i) T.-P. Lin and J. C. Peters, J. Am. Chem. Soc., 2014, 136, 13672.

9 (a) Y. Hamada, Y. Koseki, T. Fujii, T. Maeda, T. Hibino and K. Makino, Chem. Commun., 2008, 6206; (b) T. Hibino, K. Makino, T. Sugiyama and Y. Hamada, ChemCatChem, 2009, 1, 237.

10 (a) P. Yang, H. Xu and J. Zhou, Angew. Chem., Int. Ed., 2014, 53, 12210; (b) H. Xu, P. Yang, P. Chuanprasit, H. Hirao and J. Zhou, Angew. Chem., Int. Ed., 2015, 54, 5112.

11 (a) B. Loges, A. Boddien, F. Gärtner, H. Junge and M. Beller, Top. Catal., 2010, 53, 902; (b) A. Boddien, F. Gärtner, C. Federsel, P. Sponholz, D. Mellmann, R. Jackstell, H. Junge and M. Beller, Angew. Chem., Int. Ed., 2011, 50, 6411; (c) M. Grasemann and G. Laurenczy, Energy Environ. Sci., 2012, 5, 8171; (d) A. F. Dalebrook, W. Gan, M. Grasemann, S. Moret and G. Laurenczy, Chem. Commun., 2013, 49, 8735.

12 (a) B. Loges, A. Boddien, H. Junge and M. Beller, Angew. Chem., Int. Ed., 2008, 47, 3962; (b) T. C. Johnson, D. J. Morris and M. Wills, Chem. Soc. Rev., 2010, 39, 81; (c) A. Boddien, D. Mellmann, F. Gärtner, R. Jackstell, H. Junge, P. J. Dyson, G. Laurenczy, R. Ludwig and M. Beller, Science, 2011, 333, 1733; (d) J. F. Hull, Y. Himeda, W.-H. Wang, B. Hashiguchi, R. Periana, D. J. Szalda, J. T. Muckerman and E. Fujita, Nat. Chem., 2012, 4, 383; (e) Y. Maenaka, T. Suenobu and S. Fukuzumi, Energy Environ. Sci., 2012, 5, 7360; $(f)$ J. H. Barnard, C. Wang, N. G. Berry and J. Xiao, Chem. Sci., 2013, 4, 1234; $(g)$ E. A. Bielinski, P. O. Lagaditis, Y. Zhang, B. Q. Mercado, C. Würtele, W. H. Bernskoetter, N. Hazari and S. Schneider, J. Am. Chem. Soc., 2014, 136, 10234.

13 (a) R. Noyori and S. Hashiguchi, Acc. Chem. Res., 1997, 30, 97; (b) R. Kadyrov and T. H. Riermeier, Angew. Chem., Int. Ed., 2003, 42, 5472; (c) T. Ikariya and A. J. Blacker, Acc. Chem. Res., 2007, 40, 1300; (d) C. Wang, C. Li, X. Wu, A. Pettman and J. Xiao, Angew. Chem., Int. Ed., 2009, 48, 6524; (e) J.-i. Ito and H. Nishiyama, Tetrahedron Lett., 2014, 55, 3133.

14 (a) A. Togni, C. Breutel, A. Schnyder, F. Spindler, H. Landert and A. Tijani, J. Am. Chem. Soc., 1994, 116, 4062; (b) T. Imamoto, J. Watanabe, Y. Wada, H. Masuda, H. Yamada, H. Tsuruta, S. Matsukawa and K. Yamaguchi, J. Am. Chem. Soc., 1998, 120, 1635; (c) D. Liu, W. Tang and X. Zhang, Org. Lett., 2004, 6, 513; (d) T. Imamoto, K. Tamura, Z. Zhang, Y. Horiuchi, M. Sugiya, K. Yoshida, A. Yanagisawa and I. D. Gridnev, J. Am. Chem. Soc., 2011, 134, 1754.

15 W. Tang, W. Wang, Y. Chi and X. Zhang, Angew. Chem., Int. Ed., 2003, 42, 3509.

16 Y. Tsuchiya, Y. Hamashima and M. Sodeoka, Org. Lett., 2006, 8, 4851.

17 Examples: (a) J. M. Brown and P. A. Chaloner, J. Chem. Soc., Chem. Commun., 1980, 344; (b) A. S. C. Chan, J. J. Pluth and J. Halpern, J. Am. Chem. Soc., 1980, 102, 5952; (c) R. Giernoth, H. Heinrich, N. J. Adams, R. J. Deeth, J. Bargon and J. M. Brown, J. Am. Chem. Soc., 2000, 122, 12381; (d) I. D. Gridnev, N. Higashi, K. Asakura and T. Imamoto, J. Am. Chem. Soc., 2000, 122, 7183; (e) M. Kitamura, M. Tsukamoto, Y. Bessho, M. Yoshimura, U. Kobs, M. Widhalm and R. Noyori, J. Am. Chem. Soc., 2002, 124, 6649.

18 B. M. Trost, Chem. - Eur. J., 1998, 4, 2405. 